\title{
Praktik Konsumsi Jilbab Syar'i Dan Cadar Di Kalangan Perempuan Salafi Dalam Perspektif Budaya Konsumen
}

\author{
Prima Ayu Rizqi Mahanani \\ Prodi Komunikasi dan Penyiaran Islam, IAIN Kediri, Jl. Sunan Ampel No.7, Rejomulyo, Kediri, 64127 \\ E-mail: prima.ayu99@yahoo.co.id
}

\begin{abstract}
Praktik konsumsi dalam ranah pemikiran postmodernisme menjadi bahan kajian yang perlu diperhatikan. Haryanto Soedjatmiko mengkaji beberapa persoalan konsumsi dalam bukunya "Saya Berbelanja, maka Saya Ada: Ketika Konsumsi dan Desain Menjadi Gaya Hidup Konsumeris". Ia membagi perilaku konsumsi ke dalam tiga periode, yaitu periode klasik, kemunculan sosiologi konsumsi, dan periode postmodernis. Saya menggunakan perspektif budaya konsumen dalam mengamati praktik konsumsi jilbab syar'i dan cadar di kalangan perempuan Salafi karena mengaitkannya dengan persoalan identitas. Jilbab syar'i dan cadar dianggap masyarakat sebagai penanda identitas yang paling mencolok dari kelompok Salafi di antara beragam varian gaya berhijab yang ada di Indonesia. Penelitian ini bertujuan mengetahui alasan-alasan di balik kegiatan konsumsi jilbab syar'i dan cadar di kalangan perempuan Salafi. Oleh karena itu, digunakan pendekatan kualitatif dengan metode wawancara mendalam kepada pengasuh pondok pesantren Salafi di kota Kediri, yaitu Pondok Pesantren Imam Muslim Al-Atsary dan ketujuh perempuan yang menyatakan diri sebagai Salafiyah. Hasil analisis deskriptif menunjukkan praktik konsumsi jilbab syar'i dan cadar yang dilakukan oleh ketujuh informan bermula karena alasan fungsi atau nilai guna, yaitu beribadah, mengikuti Rasulullah, penghormatan diri, keamanan, perlindungan, dan kenyamanan. Konsumsi nilai guna ini berdasarkan pengamatan lebih lanjut telah memunculkan nilai tanda yang mengarah pada konsumsi tanda-tanda, seperti ketaatan, ketaqwaan, kesalehan, ketundukan, dan kepatuhan.
\end{abstract}

Keywords -: Konsumsi; Jilbab Syar’i dan Cadar; Perempuan Salafi; Budaya Konsumen.

\section{PENDAHULUAN}

Era sekarang ini (2019) ditandai dengan keberadaan masyarakat konsumen. Salah satu pemikiran Georg Simmel (1858-1918) tentang konsumsi yang membentuk konstruksi masyarakat dan menimbulkan budaya baru memperlihatkan pergeseran dari masyarakat konsumen (consumer society) menjadi budaya konsumen (consumer culture). Mike Featherstone dalam David Chaney (2006: 67) menjelaskan budaya konsumen dengan membaginya ke dalam tiga tipe: pertama, konsumerisme merupakan tahap tertentu kapitalis. Kedua, konsumerisme dan konsumsi merupakan persoalan yang lebih sosiologis mengenai relasi bendabenda dan cara melukiskan status. Ketiga, Featherstone melihat munculnya kreativitas konsumsi. Berkaitan dengan pemikiran para tokoh ini, saya tertarik untuk menyoroti praktik konsumsi jilbab dan cadar di kalangan perempuan Salafi dalam perspektif kajian budaya konsumen.

Salafi adalah setiap orang yang berada di atas manhaj salaf dalam aqidah, syariat, akhlak, dan dakwah (Jawas, 2009: 22). Salaf berasal dari kata salafa-yaslufu-salafan yang artinya kaum terdahulu. Salaf merupakan sifat yang khusus dimutlakkan kepada para sahabat, yaitu orang-orang yang mengikuti para sahabat, tabiin, dan tabiut tabiin (Mufid, 2011:223). Salafi dipahami sebagai kelompok keagamaan yang memiliki jaringan internasional dengan membawa paham keagamaan (ideologi) baru dari Timur Tengah yang dinilai berbeda dari paham keagamaan lokal yang lebih dahulu eksis (Mufid, 2011:215).

Penamaan Salafi bermula dari munculnya firqah-firqah dan terjadinya umat maka kalimat Salaf sangat tepat bagi orang yang menjaga keselamatan aqidah dan manhaj, sesuai dengan pemahaman para sahabat dan generasi yang utama. Kata Salaf adalah sinonim dari kata ahlus sunnah wal jamaah atau ahlus sunnah. Terdapat juga anggapan yang salah tentang pengertian Salafi. "Orang Salafi” disalahpahami dengan orang yang gemar mengkafirkan dan membid'ahkan (Sabrina, 2014: 3).

Jilbab syar'i dan cadar yang menjadi korpus penelitian ini merupakan sebuah benda atau material yang menjadi penanda perempuan Salafi. Para ulama Salaf merujuk aturan berjilbab dalam kitab yang ditulis oleh Muhammad Nashiruddin al-Albani. Jika seorang wanita hendak keluar dari rumahnya, ia wajib menutupi seluruh tubuhnya. Ia hendaknya tidak menampakkan sedikitpun dari perhiasannya kecuali wajah dan dua telapak tangan. Wanita hanya diperbolehkan keluar dari rumahnya dengan memakai berbagai jenis pakaian yang telah memenuhi syarat-syarat berikut ini: (1) menutupi seluruh badan selain bagian yang dikecualikan; (2) tidak dijadikan/berbentuk perhiasan (misalnya: tabarruj) ; (3) jilbab itu harus tebal, tidak tipis; (4) jilbab harus longgar, tidak ketat; (5) tidak dibubuhi parfum atau minyak wangi; (6) tidak menyerupai pakaian laki-laki; (7) tidak menyerupai pakaian wanita-wanita kafir; (8) tidak berupa pakaian syuhrah (mencolok) (Al-Albani, 2014:49). 


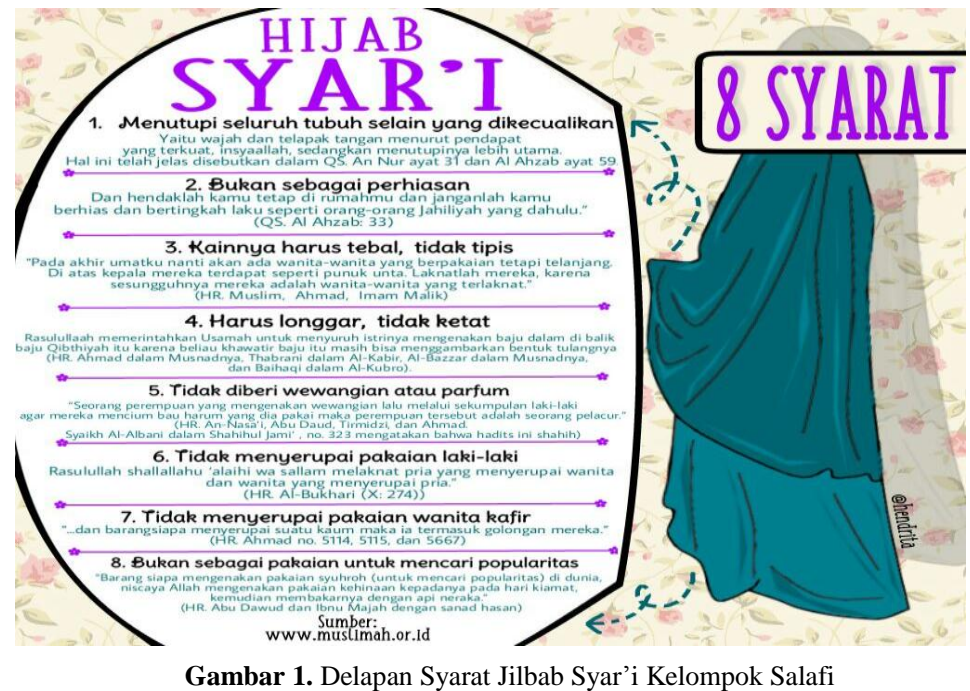

Jilbab dan cadar secara historis sudah ada sejak Islam belum ada dan memberlakukannya. Beberapa negara dan bangsa telah mengenal jilbab, seperti Yunani, Romawi, Yahudi, dan Asyria. Jilbab yang berlaku di dunia Islam menurut Karen Armstrong sebagai imitasi dari kebudayaan Kristen Yunani Bizantium yang telah lama mempraktikkan budaya kerudung dan memisahkan kaum perempuan mereka (Muslim, 2012).

Jilbab tidak hanya untuk agama Islam diperjelas oleh Fadwa Elguindi bahwa berjilbab awalnya berasal dari bangsa Mesopotamia atau Persia, dan kaum Hellenis atau Bizantium sebagai asal mula pemingitan. Justru persepsi yang lebih populer adalah jilbab itu lebih diasosiasikan pada wanita Arab dan Islam, walaupun bukti-bukti jelas menunjukkan bahwa jilbab telah lama ada di luar wilayah budaya Arab. Dalam hal ini, jilbab secara visual dan simbolis merupakan pengingat akan agama konservatif dan identitas (El Guindi, 2003:30-31).

Suzanne Brenner (1996) dalam bukunya yang berjudul "Reconstructing Self and Society: Javanese Moslem Women and 'the Veil" menceritakan fenomena "islamisasi" dalam berbusana. Berbicara tentang pakaian sesungguhnya berbicara tentang sesuatu yang sangat erat dengan diri kita. Pakaian yang kita kenakan membuat pernyataan tentang diri kita (Ibrahim, 2011: 266).

Berdasarkan pendapat tersebut terdapat relevansinya bahwa perempuan Salafi yang hidup di Indonesia sangatlah sedikit jumlahnya jika dibandingan dengan mayoritas penduduk. Meskipun dengan jumlah yang kecil tersebut, mereka berusaha untuk hidup di tengah masyarakat seperti biasa. Kita tidak dapat mengetahui secara akurat berapa jumlah orang Salafi di dunia maupun di Indonesia, khususnya jumlah perempuan Salafi yang ada (Sabrina, 2014: 18-19). Oleh karena itu, peneliti bermaksud untuk menggali lebih dalam tentang praktik konsumsi jilbab syar'i dan cadar di kalangan perempuan Salafi yang tergolong anti mainstream. Jilbab syar'i dan cadar menjadi penanda kelompok Salafi yang mengacu pada ekspresi individualitas perempuan Salafi.

\section{JILBAB SYAR'I DAN CADAR SEBAGAI PENANDA KELOMPOK SALAFI DI INDONESIA}

Keberadaan jilbab syar'i dan cadar di Indonesia turut berkembang seiring dengan perkembangan dakwah Salafi di wilayah Indonesia. Pemahaman Salafi meluas sekitar tahun 1990-an ketika iklim demokrasi di Indonesia juga mengalami peningkatan. Kehadirannya bersamaan dengan perkembangan LIPIA yang berdiri tahun 1980 dengan mendatangkan pengajar dari Timur Tengah dan akhirnya membawa manhaj ini secara lebih terbuka di Indonesia (Sabrina, 2014). Oleh karena itu, pemakaian jilbab syar'i dan cadar sebagai penanda kalangan perempuan dari gerakan keagamaan transnasional Salafi makin nyata dan jelas di Indonesia sejak pertengahan 1980-an (Hasan, 2008: 31)

Pemakaian jilbab syar'i dan cadar kelompok Salafi hingga di tahun 2019 ini terus meningkat. Semakin hari semakin baik perkembangannya dan masyarakat di luar kelompok Salafi semakin mengenali jilbab syar'i dan cadar yang menjadi identitas perempuan Salafi. Perempuan Salafi tidak semuanya bercadar, namun informan penelitian ini dipilih yang memakai cadar.

Perkembangan Salafi yang pesat di Indonesia membawa perempuan-perempuan Indonesia lebih mengenal pemahaman salafush shalih sehingga mereka yang mulai mengenal Salafi mengubah gaya berpakaiannya (Nisa, 2013: 3). Identitas yang paling menonjol dari perempuan Salafi diketahui dengan pakaian gelap dan cadar. Gambar 2 memperlihatkan ilustrasinya. 


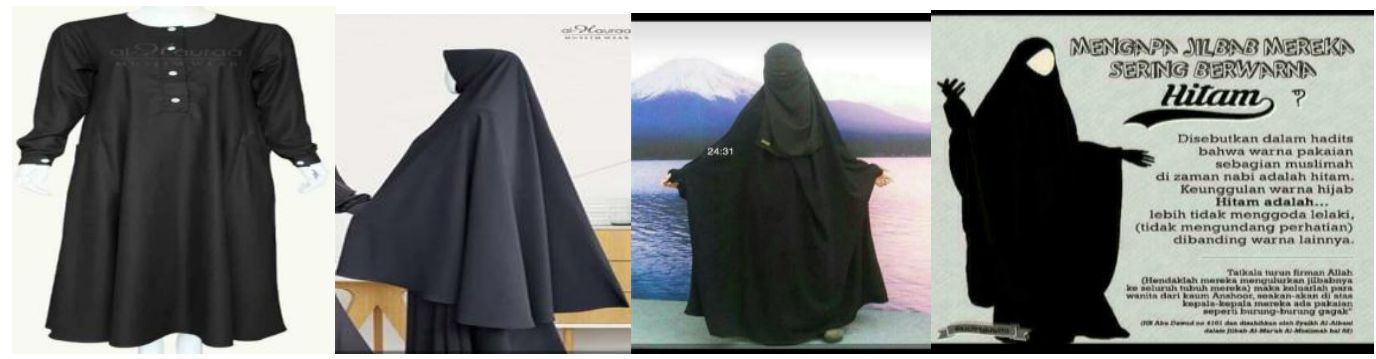

Gambar 2. Contoh Visual Jilbab Syar'i Kelompok Salafi

Ustadz Abdul Adhim menjelaskan lebih lanjut makna jilbab syar'i bagi muslimah jamaah Salafi yang merupakan cara berpakaian sesuai tuntunan dan syariat Allah yang harus ditaati berdasarkan dalil-dalil yang menjadi landasan hokum, yaitu Alquran, sunnah, qiyas, dan ijmak. Jilbab syar'i bukanlah semata budaya bangsa Arab, akan tetapi benar-benar syariat Allah yang berlaku bagi seluruh kaum muslimah. Alquran diyakini tercipta untuk seluruh umat manusia di dunia, bukan hanya khusus bagi bangsa Arab.

Syariat jilbab merupakan syariat yang telah Allah tetapkan. Kewajiban sebagai orang yang beriman menerima, tunduk, dan pasrah sepenuhnya dengan disertai keyakinan kuat. Syariat ini ada untuk kemashlahatan dan kebaikan hamba-Nya, terutama kaum muslimah, yang akan mendapatkan hikmah dalam berjilbab syar'i.

Istilah jilbab syar'i berasal dari Bahasa Arab. Jamaah Salafi memahaminya berupa kain yang menutupi seluruh tubuh atau kain yang dipakai di atas baju sesuai metode atau cara yang sudah dijelaskan oleh Allah kepada Rasul-Nya dalam agama Islam yang benar. Muhammad Nashiruddin Al-Albani (2010/2014: 114) memastikan bahwa wajah bukanlah aurat yang wajib ditutupi. Pendapat ini dinyatakan oleh mayoritas ulama. Akan tetapi, jamaah Salafi dalam praktiknya meyakini bahwa segala sesuatu yang mengandung kemaslahatannnya lebih dominan daripada kerusakannya maka hal tersebut diperintahkan, baik dalam bentuk wajib maupun sunnah. Apabila wanita yang membuka wajahnya kepada laki-laki lain mengandung berbagai kerusakan, diperintahkan menutupinya.

Al 'Utsaimin (2017: 43-44) menjelaskan sebagian kerusakan adalah fitnah (godaan) karena wanita sering menciptakan fitnah pada dirinya sendiri dengan mempercantik dan memperindah wajah serta menampakkannya dengan penampilan yang memfitnah (menggoda/merangsang). Ini merupakan pemicu kejahatan dan kerusakan sehingga kaum wanita harus menutup dirinya dari (pandangan) kaum laki-laki. Ibnu Taimiyyah berkata bahwa para wanita diperintahkan untuk mengenakan jilbab agar tidak dapat dipandangi dan jilbab sendiri harus menutup seluruh wajah atau menutup wajah dengan cadar. Wajah dan kedua telapak tangan dapat dikategorikan sebagai perhiasan yang disuruh untuk tidak diperlihatkan kepada laki-laki lain. Dengan demikian, hal yang masih halal bagi laki-laki adalah memandang pakaian luar saja.

\section{III.ANALISIS BUDAYA KONSUMEN DALAM PRAKTIK KONSUMSI JILBAB SYAR'I DAN CADAR OLEH PEREMPUAN SALAFI}

Dalam teori konsumsi, jilbab syar'i dan cadar termasuk staple goods yaitu barang-barang kebutuhan pokok. Hal ini menjadi sesuatu yang utama dan penting karena terkait persoalan menutup aurat yang diyakini oleh perempuan Salafi sebagai kewajiban. Konsumsi jilbab syar'i dan cadar tentunya terjadi pada pola-pola yang berbeda. Konsumsi mengikuti beberapa parameter diantaranya kelas, gender, etnis, agama, dan lain-lain.

Perempuan Salafi yang menjadi infoman diidentifikasi menurut usia, status, latar belakang bercadar, dan profesi. Ketujuh informan yang berhasil diwawancarai antara lain: (1) Y berusia 24 tahun, belum menikah, guru, bercadar sejak 2014; (2) A berusia 27 tahun, menikah, berjualan on line, bercadar sejak 2010; (3) R berusia 29 tahun, menikah, ustadzah, bercadar sejak 2007; (4) Ai berusia 28 tahun, menikah, berjualan online, bercadar sejak 2014; (5) D berusia 29 tahun, menikah, berjualan online, bercadar sejak 2007; (6) Rk berusia 31 tahun, menikah, berjualan online, bercadar sejak 2006; (7) F berusia 31 tahun, menikah, ibu rumah tangga, bercadar sejak 2008. Berikut ini merupakan hasil wawancara yang saya lakukan dengan melontarkan pertanyaan "Mengapa melakukan praktik konsumsi jilbab syar'i dan cadar?"

Seperti yang disampaikan Y bahwa:

"Menggunakan jilbab syar'i beserta cadar adalah cara mereka untuk taat kepada Allah, mengikuti apa yang telah Allah perintahkan di Alquran dengan mencontoh sebaik-baik penuntun yakni Rasulullah salallaahu 'alaihi wasalam. Jilbab syar'i dan cadar yang merupakan perintah dari Allah ini juga sekaligus cara bagi kami untuk menghormati diri kami sendiri. Sebab setiap wanita, Allah ciptakan dengan keindahan, dan keindahan wanita terlalu berharga untuk dibagi pada setiap mata. Juga sebagai identitas muslimah".

\section{Informan A mengatakan bahwa:}

"Sebagai seorang muslimah wajib taat kepada Allah dan Rasul-Nya. Salah satu bentuk ketaatan tersebut adalah menutup aurat dengan sempurna ketika berada di luar rumah dan atau bertemu dengan orang yang tidak halal melihat auratnya".

Penjelasan lengkap disampaikan oleh R, bahwa:

"Jilbab syar'i dan cadar bagi perempuan muslimah pada dasarnya berpakaian merupakan ibadah, di mana suatu ibadah hanya akan diterima oleh Allah dengan dua syarat: (a) Ikhlas melakukan amalan tersebut hanya untuk Allah, sebagaimana yang 
tersebut dalam hadits Ahad dari sahabat nabi, Umar radhiyallaahu'anhu bahwa sesungguhnya suatu perbuatan itu tergantung niatnya, bilamana ia niatkan untuk Allah dan Rasul-Nya maka ia hijrah kepada Allah dan Rasul-Nya. Perkara niat ini sangatlah penting. (b) Mengikuti Rasulullah, sebagaimana dalam hadits kelima dalam kitab Al Arba'in an-Nawawi dari Ummul Mu-minin "Aisyah radiyallahu'anha" mengatakan bahwa Rasulullah bersabda "barang siapa yang beramal dengan suatu amalan yang tidak pernah dicontohkan dari kami, maka amalan tersebut tertolak”. Dalam beribadah, seorang muslim tidak perlu berinovasi dengan berbagai ragam kegiatan ibadah baru. Bila hal itu dilakukan maka hilanglah hikmah diutusnya Rasul kepada umat dan agama Islam ini menjadi tidak ada batasan-batasannya karena setiap orang akan memiliki pandangan yang berbeda-beda. Adapun berhijab merupakan ibadah yang harus dilakukan dengan menggandeng kedua syarat tersebut yang juga didalamnya mengandung makna tauhid Uluhiyyah, yaitu meniatkannya hanya untuk Allah semata dan juga mengandung makna tauhid Rububiyyah, yaitu berhijab dengan mengikuti aturan-aturan Allah yang maha mengatur alam semesta ini, termasuk manusia didalamnya. Beginilah Rasulullah, sahabat-sahabat nabi, tabii'in, taabi'ut tabii'in melakukan suatu amalan yang dibangun di atas ketauhidan kepada Allah semata disetiap amalannya".

Selanjutnya informan Ai mengatakan bahwa:

"Jilbab syar'i dan cadar adalah hijab yang harus dipakai karena itu bentuk ketaatan kepada Allah dan Rasul-Nya. Ai lebih menyukai istilah hijab saja karena tidak semua yang berhijab itu bercadar dan masih ada perselisihan di antara para ulama dalam menyikapi cadar. Wanita yang tidak berhijab adalah sebagai bentuk maksiat terang-terangan sebagaimana firman Allah di surat Al Ahzab ayat 36. Hijab juga memberi rasa aman dan pintu fitnah akan berkurang. Ini juga tertuang di surat Al Ahzab ayat 59 sedangkan tidak berhijab mengundang fitnah. Hijab yang membalut tubuh wanita akan mampu meredam gejolak syahwat kaum laki-laki. Adapun wanita yang memamerkan bentuk tubuh dan perhiasannya di hadapan kaum laki-laki bukan mahram hanya akan mengundang perhatian laki-laki hidung belang dan serigala berbulu domba. Oleh karena itu, seseorang dianjurkan menundukkan pandangan demi menjaga fitnah sebagaimana firman Alloh di surat An Nur ayat 30".

Informan D menjelaskan bahwa:

"Memakai jilbab syar'i secara umum adalah kewajiban muslimah yang mana hal itu disebutkan dalam surat Al Ahzab ayat 59, surat An Nur 31, dan hadits-hadits nabi lainnya agar mendapat keutamaan atau pahala menjalankan sunnah sahabiyah dan menjaga kehormatan diri. Sebagaimana sabda nabi bahwa Islam datang dalam keadaan asing dan akan kembali asing maka beruntunglah orang-orang yang dianggap asing itu, yakni orang yang berpegang teguh pada kebenaran. Sudah sunnatulloh bahwa kebanyakan manusia itu lebih mengikuti hawa nafsu".

Informan Rk mengatakan bahwa:

"Jilbab syar'i dan cadar adalah untuk melaksanakan perintah Allah dan menutup diri dari pandangan laki-laki bukan mahram. Wanita-wanita sahabiyah di zaman Rasulullah sudah terbiasa dengan cadar sehingga lebih utama meneladani mereka. Pakai cadar setelah menikah karena motivasi suami".

Informan F menjelaskan bahwa:

"Saya memilih jilbab syar'i dan cadar karena taat pada Allah. Jilbab ini memberikan keamanan dan kenyamanan karena kecantikan wajah hanya untuk suami, merupakan identitas seorang muslimah. Dengan berjilbab seorang perempuan bisa diketahui bahwa dia adalah seorang yang beragama Islam walaupun kita tidak mengenalnya sama sekali”.

Data-data empiris tersebut selanjutnya dihubungkan dengan teori-teori budaya konsumen yang sangat membantu dalam melihat hal yang diproblematisasikan dalam tulisan ini. Dari hasil wawancara kepada ketujuh informan perempuan Salafi, mereka semua mengonsumsi jilbab syar'i dan cadar karena alasan fungsi. Berjilbab syar'i dan memakai cadar sebagai perintah Allah, dan mencontoh Rasulullah. Mereka meyakini pilihan tersebut sebagai bentuk ketauhidan, ibadah dan ketaatan, serta kewajiban setiap muslimah. Ketujuh informan memakai cadar dengan alasan niat karena Allah semata; rasa aman dan nyaman; meredam gejolak syahwat laki-laki; mengurangi masuknya fitnah; mendapat pahala; menjalankan sunnah; menjaga kehormatan diri; menutup diri dari pandangan laki-laki bukan mahram; meneladani wanita wanita-wanita sahabiyah di zaman Rasulullah; dan sebagai pengenal atau identitas.

Perempuan Salafi dalam konteks ini cenderung tidak mementingkan perkembangan mode karena berjilbab syar'i dan cadar bukan untuk berhias. Mereka mengonsumsinya disebabkan alasan syariat, yaitu muka ditutup cadar, kerudung lebar yang menjuntai sebatas selutut, gamis yang tidak ketat, tidak tipis, tidak tembus pandang, tidak bermotif, warna kain cenderung gelap, tidak memakai harum-haruman, tidak mengenakan hiasan-hiasan, tidak menyerupai pakaian laki-laki, dan tidak menyerupai pakaian wanita kafir atau fasik.

Berdasarkan teori mediated consumption, ada dua kategori besar dalam konsumsi yang dipisahkan, yaitu kelas dan status (relatif statis). Fenomena praktik konsumsi jilbab syar'i dan cadar oleh perempuan Salafi berlangsung dalam terminologi kelas karena lebih ke arah fungsi. Proses-proses konsumsi berada dalam terminologi fungsional sehingga termasuk kategori etika. Hal ini sesuai dengan pendapat Ustadz Abdul Adhim bahwa busana yang dikenakan harus memenuhi fungsi etika, yaitu menutup seluruh aurat yang tidak boleh terlihat oleh selain mahramnya dengan sempurna. Harus menutup seluruh tubuhnya dari ujung kepala sampai ujung kaki. seorang muslimah yang berbusana syar'i diniatkan untuk Allah, yaitu senantiasa mengindahkan seluruh syariat berbusana pada situasi dan dalam kondisi apapun.

Perempuan Salafi yang berjilbab syar'i dan bercadar selalu memilih warna gelap dan motif polos sehingga dikatakan tidak dinamis, tidak adaptif terhadap pasar dan fashion berdasarkan sudut pandang pemakai jilbab mainstream. Hal ini merupakan suatu pilihan etis atas jilbab syar'i dan cadar karena memenuhi fungsi-fungsi yang sudah disyariatkan oleh manhaj Salaf. 
Konsumsi tersebut mendasarkan pada nilai guna atau nilai primer dari pakaian yang berangkat dari pandangan utilitarianisme puritan.

Saya merujuk teori struktur komoditi bahwa praktik konsumsi jilbab syar'i dan cadar merupakan komoditi individu karena proses konsumsinya merupakan konsumsi individual. Hal ini merupakan komoditi personal yang tidak bisa dipertukarkan karena ada syarat keanggotaan yang melekat pada pemakainya. Konsumsi individual (individual consumption) oleh ketujuh informan berdasarkan faktor agama. Ada pertimbangan-pertimbangan ideologis dalam diri perempuan Salafi karena mengonsumsi jilbab syar'i dan cadar sebagai suatu pilihan ideologis yang menyandarkan pada paham Salafi. Dengan demikian, komoditi tersebut bisa dikatakan sebagai identitas perempuan dari kelompok Salafi sesuai penjelasan yang disampaikan oleh Y dan Rk.

Pada kasus ini, pakaian secara sosial merupakan kulit sosial dan budaya pemakainya (Nordholt dalam barnard, 2009:ix). Pakaian merupakan ekspresi identitas pribadi ataupun identitas kolektif dari komunitas tertentu ataupun kelas sosial tertentu. Praktik konsumsi yang dilakukan juga menunjukkan identitas keanggotaan suatu kelompok Islam, yaitu Salafi. Menurut pendapat Ting-Tooney (1999:40-41), dinamika utama dari identitas keanggotaan seseorang dalam suatu kelompok dan identitas pribadi terbentuk dengan jalan komunikasi simbolik kepada orang lain. Ada rasa lebih percaya diri dan merasa bermakna serta lebih dekat dan memiliki terhadap kelompok. Pada titik ini, perempuan Salafi cenderung menikmati penampilan jilbab syar'i dan cadarnya karena memberikan janji pahala dan kenyamanan identitas dalam suatu lingkungan budaya yang familiar baginya. Di sisi lain, jilbab syar'i dan cadar juga menimbulkan rasa sebagai bagian dari kelompok Salafi.

Komoditi bisa dikonsumsi karena memenuhi fungsi-fungsi tertentu. Konsumsi jilbab syar'i dan cadar pada intinya dilakukan untuk mendapatkan pahala ibadah, mengikuti perintah agama karena merupakan suatu kewajiban, dan ketauhidan kepada Tuhan. Selain itu, jilbab syar'i dan cadar dikonsumsi karena untuk kontrol diri agar hidupnya lebih terjaga dari segala macam godaan dan kejahatan.

Mengonsumsi jilbab syar'i dan cadar dalam gagasan teori skala komoditas dan gaya hidup tergolong skala makro sosial bahwa komoditi yang digunakan menyangkut dengan way of life, yaitu berdasarkan perintah Tuhan. Dalam hal ini, sesuatu yang mempengaruhi pandangan hidup perempuan Salafi mempunyai arti ideologis, yaitu memakai jilbab syar'i dan cadar karena alasan agama.

Pada konteks tertentu, fakta yang ditemukan dapat dikatakan skala meso sosial karena ketika komoditi hadir diakibatkan interaksi sosial yang lebih bersifat interaktif. Dengan demikian, mengonsumsi jilbab syar'i dan cadar karena dikonstruksikan oleh orang lain, seperti yang terjadi pada informan Rk. Dia menggunakan jilbab syar'i dan cadar setelah menikah karena dimotivasi suaminya yang bermanhaj Salaf. Pilihan dalam konsumsi ini merupakan pilihan sosial bukan individual. Keputusan untuk berjilbab syar'i dan bercadar dipilihkan oleh orang lain.

Cara kita berpakaian juga sangat ditentukan oleh pressure group (social pressure). Ada kecenderungan tekanan kelompok dalam proses konsumsi jilbab syar'i dan cadar. Pilihan-pilihan perempuan Salafi dibuat oleh kelompok yang merupakan komoditi sosial. Hal ini seperti yang dialami Y bahwa pilihan mengonsumsi jilbab syar'i dan cadar setelah mengikuti kajian Salafi.

Praktik konsumsi jilbab syar'i dan cadar yang dilakukan Y sesuai dengan teori konsumsi tentang social-genesis of consumption yang merupakan suatu proses konsumsi terlahir karena tekanan-tekanan kelompok. Hal ini bertujuan untuk memenuhi kebutuhan sosial yang menyangkut interaksi antar orang atau kelompok karena adanya tekanan sosial, yaitu tekanan kelompok Salafi, sehingga keberadaan peer groups (teman sesama jamaah Salafi) penting sekali terhadap kegiatan konsumsi yang dilakukan.

Di sisi lain, praktik konsumsi jilbab syar'i dan cadar juga merupakan produksi kebudayaan. Aktivitas konsumsi yang dilakukan perempuan Salafi merupakan aktivitas produksi kebudayaan, yaitu penanaman nilai-nilai kesalafian. Dengan demikian, konsumsi jilbab syar'i dan cadar dikatakan sebagai production of culture karena mempunyai potensi untuk memproduksi nilai-nilai baru yang kemudian bisa menggeser nilai-nilai yang sudah berkembang lebih dulu.

Dalam wawancara lebih lanjut, ditemukan fakta bahwa dalam konsumsi jilbab syar'i dan cadar ada hasrat dari ketujuh informan untuk menggantikan jilbab atau mengubah jilbab populer yang ditandai dengan misi berdakwah melalui lisan maupun tulisan secara bertahap. Perempuan Salafi mengambil jalan dengan berbagi ilmu dan mendoakan muslimah yang belum berjilbab syar'i dan bercadar agar menutup aurat secara sempurna sesuai syariat. Mereka berharap ada petunjuk dan hidayah dari Allah untuk memakai jilbab syar'i dan cadar. Akan tetapi, hal ini dipahami oleh perempuan Salafi dengan ukuran tergantung, yaitu diserahkan kepada orang yang bersangkutan apakah ingin mencari hidayah atau tidak dan atas ridho dan taufik (pertolongan) Allah untuk memberikan hidayah-Nya atau tidak. Dengan demikian, melalui misi dakwah untuk merangkul muslimah lain agar mau berjilbab syar'i dan bercadar yang bisa dimulai dari keluarga terdekat terlebih dahulu.

Konsumsi jilbab syar'i dan cadar yang dilakukan perempuan Salafi ada kecenderungan upaya untuk mengubah tata nilai suatu masyarakat yang sudah ada sebelumnya. Ada kemampuan untuk mendobrak nilai-nilai tertentu yang sudah mapan di masyarakat. Hal ini terkait pernyataan informan bahwa ada pemahaman yang keliru dengan mengartikan berpakaian sesuai syariat adalah budaya. Cadar menurut mereka bukanlah merupakan budaya Arab karena ada kisah dalam suatu hadits shahih saat turun perintah agar wanita berhijab maka seketika itu juga wanita-wanita di zaman Rasulullah yang telah beriman kepada Islam langsung menutupkan tubuh-tubuh mereka, sampai hanya terlihat matanya saja. Berdasarkan kisah tersebut, jilbab syar'i dan cadar tidak bisa dikatakan sebuah budaya. Kalau disebut budaya, saat itu muslimah tentunya tidak perlu bersikap demikian. 
Ketujuh informan meyakini upaya untuk menutup aurat dengan jilbab syar'i dan cadar tidak sama dengan memakai pakaian jeans yang sudah biasa dalam budaya Indonesia modern atau Amerika dan Eropa. Cara berpakaian yang sesuai syariat tidak bisa dikategorikan sebagai budaya. Kedua hal tersebut diyakini perempuan Salafi sebagai sesuatu yang jelas-jelas tidak sama. Berjilbab yang sesuai syariat merupakan perintah Tuhan sedangkan berbusana daerah atau berpakaian modern adalah buatan manusia.

Hasrat tersebut bisa dipahami karena dibentuk oleh hal-hal yang bersifat external need yang bersifat basic dan ada secara intrinsik pada setiap individu. Hal ini dialami oleh ketujuh informan bahwa hasrat mengubah jilbab populer dengan jilbab syar'i dan cadar karena mengemban misi dakwah dan melihat realita sekarang ini di mana lingkungan sudah tidak lagi kondusif untuk menundukkan pandangan selain dengan jilbab syar'i dan cadar. Mereka sangat yakin untuk berjilbab syar'i dan mengenakan cadar karena ada dalil ayat jilbab dalam Alquran dan Alhadits.

"Perlawanan" perempuan Salafi terhadap jilbab yang dianggap tidak sesuai syariat dilakukan dengan tetap semangat dan terus berdakwah. Mereka melihat realita sekarang ini yang semakin tidak kondusif lagi untuk menundukkan pandangan selain dengan jilbab syar'i dan cadar. Apalagi di zaman yang banyak fitnah dan kerusakan seperti sekarang ini, keputusan untuk memakai cadar dinilai lebih utama. Pada titik ini, ada potensi dari perempuan Salafi untuk counter culture ketika konsumsi jilbab syar'i dan cadar dimaknai sebagai budaya tandingan.

Asumsi saya terkait praktik konsumsi jilbab syar'i dan cadar yang berpotensi counter culture ini menjadi bagian yang tidak terpisahkan dalam tatanan struktur sosial untuk mempertahankan dominasi sosial dan budaya. Hal ini mengungkapkan kepentingan akan pemeliharaan dominasi sosial dan budaya tertentu. Dasar kecurigaan saya adalah jangan-jangan itu merupakan sebuah praktik relasi kuasa dan dominasi tertentu yang perlu dikaji lebih mendalam di riset selanjutnya. Kita bisa menjelaskan sebuah ideology dan power yang beroperasi dalam komunitas tersebut. Ada kekuasaan yang beroperasi dalam diri perempuan Salafi.

Pada konteks tersebut, konsumsi mempunyai kekuatan untuk menghadirkan nilai-nilai yang berbeda dengan jilbab yang tergolong wacana dominan, bahkan nilai yang bisa menimbulkan konflik. Hal ini dipicu oleh adanya berbagai pola dalam penstrukturan masyarakat untuk mengatasi kultur masyarakat yang beragam agar ditemukan identitas tertentu. Penstrukturan sebagai instrumen dari kebudayaan menjaga suatu nilai-nilai yang diyakini agar tetap terinternalisasi dengan baik.

Di sisi lain, mengonsumsi jilbab syar'i dan cadar bisa juga dimaknai sebuah penyamaran. Salah satunya melalui fashion yang dipakai untuk menyamarkan identitas mereka. Dalam konteks ini, fashion sebagai game bahwa penampilan sebagai sarana ekspresi diri dan bisa juga untuk menyembunyikan siapa dia sesungguhnya, yaitu dirinya yang lain. Fashion sebagai permainan bisa dipermainkan oleh perempuan Salafi. Hal ini mengarahkan pada jilbab syar'i dan cadar sebagai arena kontestasi makna. Kebanyakan orang sering terjebak untuk melihat satu dimensi saja sehingga penelitian lebih lanjut terkait permasalahan ini perlu dilakukan.

Fashion dilihat tidak hanya satu dimensi, tapi ada banyak dimensi. Untuk penyelidikan selanjutnya, kecurigaan ini bisa ditanyakan kepada perempuan Salafi apakah mereka pernah melakukan tindakan yang dikategorisasikan fashion sebagai permainan. Fashion dalam konteks ini merupakan arena kontestasi beragam makna. Bahkan, makna yang dikonstruksikan seorang konsumen pun bisa cair, berubah-ubah dan bergeser. Wawancara lebih mendalam berikutnya kepada perempuan Salafi bisa diketahui dari otobiografi dalam fashion yang mendeskripsikan dan menjelaskan pergeseran makna dengan memakai paradigma Marxis.

Fashion dalam pemikiran Marxis dikatakan sarana ekspresi kebebasan individu yang berangkat dari free choice ideology (FCI). FCI merupakan basis feminisme tertua sejak gelombnag pertama bahwa perempuan sebagai perempuan mempunyai ideologi pilihan bebas dan otonomi penuh atas tubuh atau dirinya. Perempuan ingin berpakaian seperti apa dan bagaimana sepenuhnya merupakan hak dirinya. Mengonsumsi jilbab syar'i dan cadar bisa juga dikatakan bukan persoalan teologis. Dengan memakai frame dalam konteks gaya hidup, pertanyaannya adalah citra apa yang ingin dibangun? Bagaimana resepsi masyarakat pada citra yang dibangun oleh perempuan Salafi. Tugas peneliti culture studies mendeskripsikan dan menjelaskan pergeseranpergeseran makna itu.

\section{IV.PENUTUP}

Praktik konsumsi bisa digunakan untuk pembeda kelas atau golongan atau kelompok yang merupakan pilihan sadar daripada keniscayaan kultural. Pembedaan diri dari golongan atau kelas yang lain (class distinction) semakin diperlukan. Begitu juga dengan fenomena jilbab syar'i dan cadar yang dikonsumsi oleh perempuan Salafi. Jilbab syar'i dan cadar merupakan sebuah benda atau material yang menjadi penanda dari perempuan Salafi. Sistem penanda yang merujuk pada dirinya sendiri. Ada benda-benda konsumsi (jilbab syar'i dan cadar) yang melekat dalam tubuhnya. Benda tersebut menjadi penanda kelas dan penentu posisi. Ada nilai yang dikonstruksikan atas benda.

Orang yang mengonsumsi jilbab syar'i dan cadar akan secara aktif mengonstruksikan makna. Makna dibangun dalam hubungan antar tanda. Makna bisa dibangun tapi tidak bisa lepas dari kode kulturalnya. Pembedaan yang langsung kentara memang dapat dilihat dari busana yang dikonsumsi.

Praktik konsumsi jilbab syar'i dan cadar yang dilakukan oleh perempuan Salafi bermula karena alasan fungsi atau nilai guna, yaitu penghormatan diri, keamanan, perlindungan, dan kenyamanan. Konsumsi nilai guna ini berdasarkan pengamatan lebih lanjut telah memunculkan nilai tanda yang mengarah pada konsumsi tanda-tanda, seperti ketaatan, ketaqwaan, kesalehan, 
Website : http://sosial.unmermadiun.ac.id/index.php/sosial

ketundukan, dan kepatuhan. Komoditas tanda-tanda tersebut bersifat sistem penanda-penanda yang mengacu pada diri perempuan Salafi.

Ada nilai-nilai yang dikonstruksikan pada jilbab syar'i dan cadar. Penggunaan jilbab syar'i merupakan perintah Allah, mencontoh Rasulullah, sebagai bentuk ketauhidan, untuk beribadah, dan kewajiban setiap muslimah sedangkan pemakaian cadar diniatkan karena Allah semata, meredam gejolak syahwat laki-laki, mengurangi masuknya fitnah, mendapat pahala, mengharap hadiah surga, menjalankan sunnah, menutup diri dari pandangan laki-laki bukan mahram, dan meneladani wanita wanita-wanita sahabiyah di zaman Rasulullah.

\section{DAFTAR PUSTAKA}

Ahmad, Leila. 2000. Wanita dan Gender dalam Islam: Akar-Akar Historis Perdebatan Modern. Diterjemahkan oleh Nasrulloh, M.S., Jakarta: Lentera. Al-Albani, Muhammad Nashiruddin. 2014. Kriteria Busana Muslimah, Jakarta: Pustaka Imam Asy-Syafii.

Barnard, Malcolm. 2011. Fashion sebagai Komunikasi. Yogyakarta: Jalasutra.

Brenner, Suzanne. 1996. Reconstructing Self and Society: Javanese Muslim Women and The Veil, American Ethnologist, Published by: Wiley on Behalf of The American Anthropological Association, Vol. 23, No. 4, Nov., pp. 673-697.

Chaney, David. 2011. Lifestyles: Sebuah Pengantar Komprehensif. Diterjemahkan oleh Nuraeni. Yogyakarta: Jalasutra.

El Guindi, Fadwa. 2003. Veiling Resistance in Feminist Postcolonial Theory: A Reader. Ed. Reina Lewis and Sara Mills. Edinburgh: Edinburgh UP.

Hasan, Noorhaidi. 2008. Laskar Jihad. Jakarta: LP3ES.

Ibrahim, Idi Subandy. 2011. Budaya Populer sebagai Komunikasi. Yogyakarta: Jalasutra.

Jawas, Yazid bin Abdul Qadir. 2008/2010. Mulia dengan Manhaj Salaf. Bogor: Pustaka At-Taqwa.

Mufid, Ahmad Syafi'i. 2011. Perkembangan Paham Keagamaan Transnasional di Indonesia. Jakarta: Kementerian Agama Republik Indonesia.

Muslim, Nur Aziz. 2012. Hijab Antara Tradisi dan Normativitas: Menilik Pemikiran Qasim Amin dalam Mengangkat Martabat Perempuan, Jurnal Studi Gender Indonesia, Pusat Studi Gender UIN Sunan Ampel Surabaya, Vol. 03, No. 01, Agustus, hal. 63-84.

Sabrina, Firza. 2014. Perempuan dan Media: Perempuan Salafi dan Aksesibilitas Media (Studi Etnografi pada Perempuan Salafi di Wisma Qaanitah Yogyakarta. UGM Yogyakarta.

Ting-Tooney, Stella. 1999. Communicating Across Cultures. New York dan London: The Guilford Press.

Nisa, Eva. F. 2013. The internet Subculture of Indonesian Face-Veiled Women. International Journal of Cultural Studies. SAGE Publications.

Internet:

https://www.muslimah.or.id/1185-mengenal-manhaj-salaf, diakses 27 Februari 2017.

Sumber Lain:

Catatan Materi Kuliah Gaya Hidup dan Budaya Konsumen dari Prof. Dr. Irwan Abdullah. 2016.

Catatan Materi Kuliah Gaya Hidup dan Budaya Konsumen dari Dr. Budiawan. 2016. 